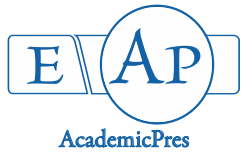

Lincy A et al. (2021)

Notulae Scientia Biologicae 13(1):10862

DOI: $10.15835 / \mathrm{nsb} 13110862$

Research Article

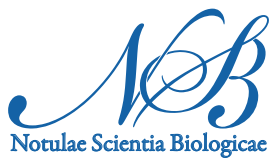

\title{
Molecular identification and genetic variation studies in economically important cephalopods at Beypore Fishing Harbour (Kozhikode), South West coast of India
}

\author{
Alex LINCY ${ }^{1 *}$, Madhavankonath K. ANIL ${ }^{2}$, \\ Muthusamy THANGARAJ ${ }^{3}$, Jean J. JOSE ${ }^{1}$ \\ ${ }^{1}$ University of Kerala, St. Gregorios College, Department of Zoology, Kottarakara-691531, India; \\ lincyjean@gmail.com ("*orresponding author);cobia2017sgc@gmail.com \\ ${ }^{2}$ Central Marine Fisheries Research Institute, Regional Centre, Vizhinjam-695521, Kerala, India; mkanil65@gmail.com \\ ${ }^{3}$ Annamalai University, Faculty of Marine Sciences, Centre of Advanced Study in Marine Biology, Parangipettai-608502, \\ Tamil Nadu,India; coralholder@yahoo.com
}

\begin{abstract}
Cephalopods are ecologically and economically important marine groups in the world. Biodiversity description is essential for sustainable utilization of natural resources and to characterize biological entities for conservation. DNA barcoding is an effective tool used for identification of organisms at species level and is been widely used for delineate several ambiguity species. In this study, partial sequence of mitochondrial cytochrome c oxidase 1 (CO1) gene with a mean size of 680 bp was amplified by universal primers. Totally 13 individuals of Cephalopods comprising of three species, were barcoded and genetic variation was analysed. The maximum A+T content (67.60\%) was recorded in Cistopus indicus and minimum (63.70\%) in Sepioteuthis lessoniana. The maximum K2P distance $(0.268)$ was found between the genus Cistopus and Sepioteuthis whereas the minimum distance (0.188) was observed between Uroteuthis and Sepia. The neighbour joining tree revealed three distinct clades represents Loligonidae, Sepiidae and Octopodidae with high boot strap values. However, Sepioteuthis lessoniana is showing a bifurcated branch and it may due to the co-occurring of cryptic species and till date this species is treated as Sepioteuthis lessoniana complex.
\end{abstract}

Keywords: cephalopods; cytochrome c oxidase 1; DNA barcoding; phylogenetic analysis

\section{Introduction}

Cephalopods are coming under the phylum Mollusca, which is having two major groups, the Nautiloids and Coleoids. Nautiloids are covered by an external shell and the Coleoids are lacking this external shell. Coleoids comprises of four orders: Sepioidea, Teuthida, Vampyromorphida and Octopodida. (Yalla and Mohanraju, 2019). They inhabit mainly in coral reef ecosystems taking advantages of this ecosystem as spawning ground, egg placement site, and shelter for the young ones (Pratasik et al., 2019). Cephalopods are known to have diverse body patterns that can immediately change their colour, being controlled by its chromatophore system (Hanlon et al., 2009). The major cephalopod groups are easily distinguishable by

Received: 05 Dec 2020. Received in revised form: 01 Feb 2021. Accepted: 02 Feb 2021. Published online: 10 Feb 2021.

From Volume 13, Issue 1, 2021, Notulae Scientia Biologicae journal will use article numbers in place of the traditional method of continuous pagination through the volume. 
morphological and anatomical features. But morphological features can facilitate in identification only up to sub family or generic level (Voight, 1993). It is very difficult to discriminate at species level based on traditional morphological characters (Herke and Foltz, 2002). In Indian seas about 210 species were recorded (Appukuttan, 1996), of which 80 species are of commercial importance (Yalla and Mohanraju, 2019).

The present study focuses on genetic variations using DNA sequence of mitochondrial genome as DNA barcode. DNA barcoding is the latest molecular tool that uses a short genetic marker of an organism's genome to identify them at species level (Yalla and Mohanraju, 2019). Cytochrome c oxidase 1 gene (CO1) is the most common mitochondrial gene used for species identification (Folmer et al., 1994) due to its conserved nature among the protein coding genes. It has become a standard tool of molecular taxonomy and species identification (Ratnasingham and Hebert, 2007). A CO1 gene sequence determines relationships within the coleoid cephalopods at higher level (Carlini and Graves, 1999). Molecular techniques have been well applied for stock discrimination studies in fisheries (Murphy et al., 2002) and can provide the basis for better management of whole populations and sustainable fisheries (Pratasik et al., 2019). This study aims to examine the genetic characteristics of some cephalopod species collected from the Beypore Fishing Harbour, Kozhikode, South west coastal waters of India.

\section{Materials and Methods}

\section{Sample collection}

Cephalopod samples such as Sepia pharaonis, Uroteuthis duvauceli and Sepioteuthis lessoniana were collected from the Beypore Fishing Harbour, Kozhikode (Latitude $11^{\circ} 09^{\prime} \mathrm{N}$; Longitude $75^{\circ} 48^{\prime} \mathrm{N}$ ). The collected samples were transported to the laboratory in ice boxes. All the specimens were identified morphologically and anatomically using FAO identification keys (FAO, 2006). Tissue samples of all individuals were stored in $95 \%$ ethanol for further molecular studies.

\section{Genomic DNA isolation, amplification and sequencing}

Total genomic DNA was isolated from the tentacle muscle tissue according to method of Sambrook et al. (2001). The isolated DNA was quantified by an UV spectrophotometer. The cytochrome c oxidase subunit I (COI) gene was amplified in a $50 \mu \mathrm{l}$ volume with $100 \mathrm{ng}$ template DNA, $10 \mu \mathrm{mol}$ of each specific primer, 200 $\mu \mathrm{M}$ of each dNTPs, 1.0 units of Taq DNA polymerase and $1 \times$ Taq buffer containing $1.5 \mathrm{mM} \mathrm{MgCl} 2$. The universal primers LCOI 1490F1-5'GGTCAACAAATCATAAAGATATTGG3' and HCOI 2198 5'TAAACTTCAGGGTGACCAAAAAATCA3' (Folmer et al., 1994), were used to amplify the COI gene. The PCR conditions were initial denaturation at $95^{\circ} \mathrm{C}$ for 5 min followed by 35 cycles of $45 \mathrm{sec}$ at $94^{\circ} \mathrm{C}, 45$ sec at $54^{\circ} \mathrm{C}, 60 \mathrm{sec}$ at $72{ }^{\circ} \mathrm{C}$ and final extension at $72{ }^{\circ} \mathrm{C}$ for $10 \mathrm{~min}$. The PCR products were visualized on $1.5 \%$ agarose gels. The amplified product was sequenced by a commercial sequencing facility (Eurofins, Bangalore).

\section{Sequence analysis}

The thirteen sequences of the present study have been submitted to the NCBI GenBank through BankIt portal and accession number will be assigned soon. The size of each sequence was $684 \mathrm{bp}$. The amplified sequences belonging to COI gene were confirmed by percent similarity in the NCBI's BLASTn program. Higher percentage similarity (95-100\%) against the reference sequence was used to confirm the identity of the species. Thirteen nucleotide sequences of three taxa from the present study along with six reference sequences from GenBank (Badhe et al., 2013) were incorporated for the phylogenetic study analysis. Nucleotide composition, genetic variation and pairwise evolutionary distance among sequences were estimated by Kimura 2-parameter (K2P) method (Kimura, 1980) using the software program MEGA 5 (Kumar et al., 2011). The 
maximum likelihood (ML) tree was constructed and to verify the robustness of the internal nodes of these trees, bootstrap analysis was carried out using 1000 pseudo replications.

\section{Results and Discussion}

\section{Nucleotide composition}

All the sequences were conceptually translated into proteins using invertebrate mitochondrial genetic code translation pattern. There were no insertions, deletions or stop codons in any of the obtained sequences. The nucleotide frequency in five cephalopod species is given in Figure 1. Thiamine was more (0.372) and guanine was less $(0.152)$ frequency in $C$. indicus. Whereas, thiamine was less $(0.354)$ and guanine frequency was more (0.168) in $U$. edulis when compared with $C$. indicus. The fours nucleotides i.e. A, T, G and C were divided into two groups as $\mathrm{A}+\mathrm{T}$ and $\mathrm{C}+\mathrm{G}$. The maximum $\mathrm{A}+\mathrm{T}$ content $(67.60 \%)$ was recorded in $C$. indicus and minimum $(63.70 \%)$ in $S$. lessoniana. Similarly, the maximum C+G value of $36.30 \%$ was observed in $S$. lessoniana and least content of $32.40 \%$ was estimated in $C$. indicus.

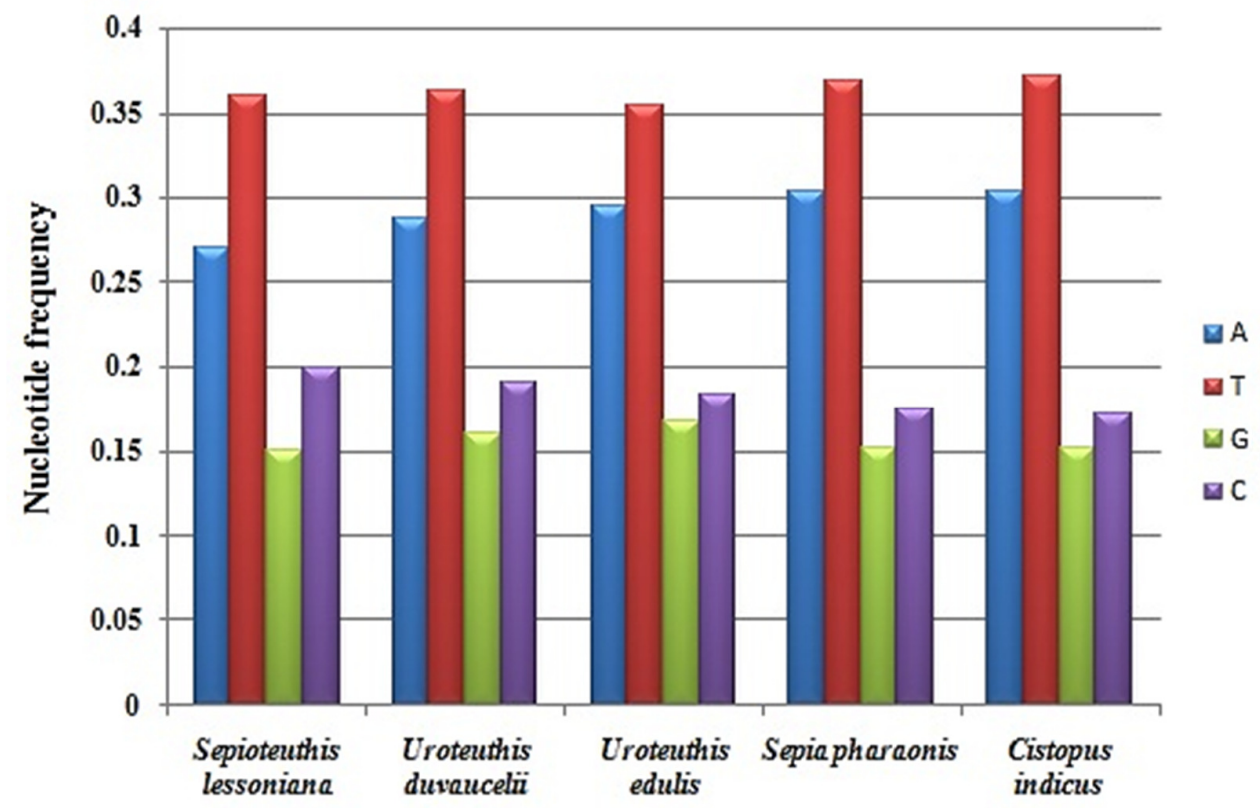

Figure 1. Nucleotide frequency of CO1 gene in cephalopod species

\section{Genetic distance between families}

The genetic distance was measured by K2P parameter in three cephalopod families in this study and Lower level of value was observed among the families. The maximum K2P distance ( 0.262$)$ was found between Octopodidae and Loligonidae. Whereas, the minimum K2P distance of 0.194 was observed between Loligonidae and Sepiidae.

\section{Genetic distance between genus}

Genetic distance between genus and the result are shown in Table 1. The maximum K2P distance (0.268) was found between the genus Cistopus and Sepioteuthis whereas the minimum distance (0.188) was observed between Uroteuthis and Sepia. The maximum K2P distance within genus was observed in Sepioteuthis (0.057). The intra genus K2P genetic distance in Sepia was zero. 
Table 1. K2P genetic distance between cephalopod species based on CO1 gene sequence

\begin{tabular}{|c|c|c|c|c|c|}
\hline Species & S. pharaonis & U.duvaucelii & S. Iessoniana & U. edulis & C. indicus \\
\hline $\begin{array}{c}\text { Sepia } \\
\text { pharaonis }\end{array}$ & 0.000 & & & & \\
\hline $\begin{array}{l}\text { Uroteuthis } \\
\text { duvaucelii }\end{array}$ & 0.188 & 0.004 & & & \\
\hline $\begin{array}{c}\text { Sepioteuthis } \\
\text { lessoniana }\end{array}$ & 0.201 & 0.211 & 0.057 & & \\
\hline $\begin{array}{l}\text { Uroteuthis } \\
\text { edulis }\end{array}$ & 0.188 & 0.185 & 0.225 & 0.003 & \\
\hline $\begin{array}{l}\text { Cistopus } \\
\text { indicus }\end{array}$ & 0.236 & 0.265 & 0.268 & 0.248 & 0.030 \\
\hline
\end{tabular}

\section{Phylogenetic relationship}

The evolutionary history was inferred by using the Maximum Likelihood method based on the K2P model. Initial tree(s) for the heuristic search were obtained automatically, when the number of common sites was $<100$ or less than one fourth of the total number of sites in the maximum parsimony method. The tree was drawn to scale, with branch lengths measured in the number of substitutions per site. The neighbour joining tree clearly demonstrates the efficacy of COI gene in discriminating cephalopod individuals both at conspecific and congeneric levels (Figure 2). The genus and species level discrimination can be ascertained by strong bootstrap support of over 99\%. All the cephalopod families formed a distinct clade. Topologically two major clades were formed; one major clade comprising two families with four species (Sepia pharaonis, Uroteuthis duvauceli, Sepioteuthis lessoniana and Uroteuthis edulis). The next clade consisting of only Octopodidae. From this NJ tree it can be also visualized that the clade entailing Sepiidae, Loliginidae and Octopodidae family showed perfect distinction between the genus within the family by high bootstrap values $(67-100)$.

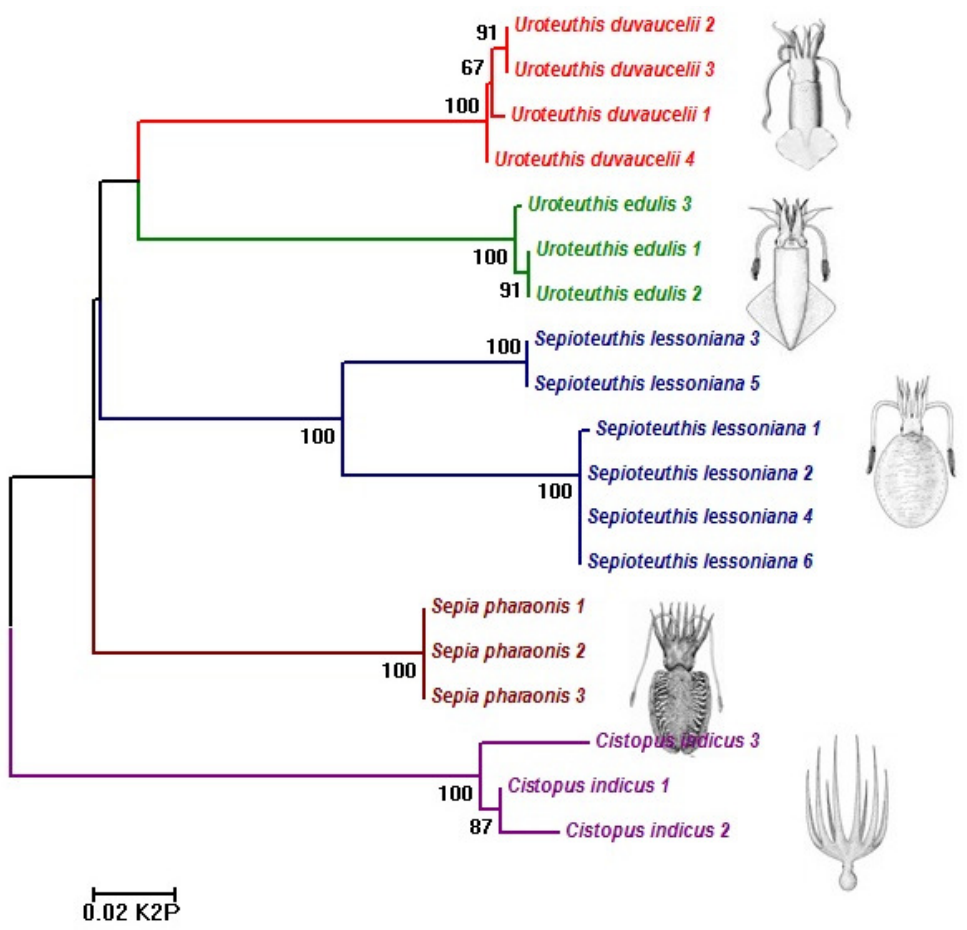

Figure 2. NJ Phylogeny of cephalopod species based on CO1 gene sequence with bootstrap values 
Due to the non distinguishable morphological characters we can use molecular tools to detect cryptic species via the phylogenetic species concept (Bickford et al., 2007). CO1 gene got more popular due to the universal primers potential to represent a broad range of phylogenetic signal than other mitochondrial genes (Hebert et al., 2003). Using this molecular technique, many marine species that were once considered as complex are actually comprised of many genetically distinct species (Cheng et al., 2014). The data collected in this study allowed for a robust and extensive phylogenetic assessment of five cephalopod species and the COI gene clearly delineate the five species. The divergences found between lineages exceed values commonly observed for congeneric species (Avise, 2000) and similar very deep divergences in mitochondrial gene regions have been reported in cephalopods (Strugnell and Lindgren, 2007) including the Sepia pharoanis (Anderson et al., 2011) and Sepioteuthis lessoniana (Allcock et al., 2011) complexes. The average transversional pairs ( $\mathrm{Tv}=$ 51) were ten times lesser than transitional pairs $(\mathrm{Ti}=523)$ with an average ratio of 10.25 . This value was relatively more when comparing with earlier study by Badhe et al. (2013) in cephalopods. The mean sequence length in this study was $680 \mathrm{bp}$ and each of this sequence clustered tightly with conspecific sequences. Same kind of result was also reported by Badhe et al. (2013). Hajibabaei et al. (2005) stated that at least 100-200bp of $\mathrm{CO} 1$ gene sequence is enough to discriminate a species. The average GC content in cephalopod CO1 gene was $34.8 \%$ which is lower than teleost's CG content where it was $47.10 \%$ as per Ward et al. (2005). The barcoded sequences clearly demonstrated the taxonomic status of all the five species studied.

Hebert (2004) insisted a standard barcode sequence threshold level of 10X the mean intraspecific genetic variation for differentiate species. This barcoding gap is sufficient to discriminate the cephalopods to their taxonomic position (Badhe et al., 2013). The COI genetic variation in cephalopods increased from lower taxonomic level to higher levels and supported and demonstrated the genetic divergence at the species level. This observation supports the previous findings of Hubert et al. (2008). The Neighbour Joining tree revealed distinct clades where closely related species were clustered under same nodes while distantly related species were clustered under separate nodes with high boot strap values (Figure 2). But, S. lessoniana is showing a bifurcated branch and it may due to the co-occurring of cryptic species and till date this species is treated as $S$. lessoniana complex.

\section{Conclusions}

The results from our data clearly discriminated all the species collected from Beypore Fishing Harbour, Kozhikode and were congruent with the taxonomic divisions of the cephalopods. However, for defining new species some more molecular markers might be necessary for accurate description.

\section{Authors' Contributions}

Work designed by: LA, MKA. Animals collected and identified by: LA, JJJ. Experiments performed by: LA, JJJ, MT. Data analyzed by: LA, JJJ, MT. Reagents/materials/analysis tools provided by: MKA, MT. Paper written by: LA, JJJ, MT. The final draft edited by: MKA. All authors read and approved the final manuscript.

\section{Acknowledgements}

We thank Dr. A. Chandran, Director, School of Applied Life Sciences, Pathanamthitta, Kerala, India for the guidance provided during the field work at Beypore. This paper is a part of the Ph. D thesis work of Corresponding Author registered in the Department of Aquatic Biology \& Fisheries, University of Kerala, India. 


\section{Conflict of Interests}

The authors declare that there are no conflicts of interest related to this article.

\section{References}

Allcock AL, Barratt I, Eleaume M, Linse K, Norman MD, Smith PJ, ... Strugnell JM (2011). Cryptic speciation and the circumpolarity debate: a case study on endemic Southern Ocean octopuses using the CO1 barcode of life. Deep Sea Research Part II: Topical Studies in Oceanography 58:242-249. https://doi.org/10.1016/j.dsr2.2010.05.016

Anderson FE, Engelke R, Jarrett K, Valinassab T, Mohamed KS, Asokan PK, ... Dunning M (2011). Phylogeny of the Sepia pharaonis species complex (Cephalopoda: Sepiida) based on analyses of mitochondrial and nuclear DNA sequence data. Journal of Molluscan Studies 77:65-75. http://dx.doi.org/10.1093/mollus/eyq034

Appukuttan K (1996). Marine molluscs and their conservation. In: Menon NG, Pillai CSG (Eds). Marine Biodiversity, Conservation and Management CMFRI pp 66-80. http://eprints.cmfri.org.in/id/eprint/4097

Avise JC (2000). Phylogeography: The history and formation of species. Harvard University Press, Cambridge, MA, pp 447.

Badhe MR, Pavan-Kumar A, Gireesh-Babu P, Nandanpapwar P, Chaudhari A, Jaiswar AK, ... Lakra WS (2013). DNA barcoding of selected cephalopods from Indian coast. Indian Journal of Animal Science 83(8):862-866.

Bickford D, Lohman DJ, Sodhi NS, Ng PKL, Meier R, Winker K, ... Das I (2007). Cryptic species as a window on diversity and conservation. Trends in Ecology and Evolution 22:148-155. https://doi.org/10.1016/j.tree.2006.11.004

Carlini DB, Graves JE (1999). Phylogenetic analysis of cytochrome c oxidase I sequences to determine higher-level relationships within the coleoid cephalopods. Bulletin of Marine Science 64:57-76.

Cheng SH, Anderson FE, Bergman A, Mahardika GN, Muchlisin ZA, Dang BT, ... Barber PH (2014). Molecular evidence for co-occurring cryptic lineages within the Sepioteuthis cf. lessoniana species complex in the Indian and IndoWest Pacific Oceans. Hydrobiologia 725:165-188. https://doi.org/10.1007/s10750-013-1778-0

FAO (2006). Western Indian Ocean. Fishing area 51. Volumes I-VI. FAO Species Identification Sheets for Fishery Purposes. Rome, FAO. 2006. CD-ROM.

Folmer O, Black M, Hoeh W, Lutz R, Vrijenhoek R (1994). DNA primers for amplification of mitochondrial cytochrome c oxidase subunit I from diverse metazoan invertebrates. Molecular Marine Biology and Biotechnology 3:294299.

Hajibabaei M, Smith AA, Janzen DH, Rodriguez JJ, Whitfield JB, Hebert PDN (2005). A minimalist barcode can identify a specimen whose DNA is degraded. Molecular Ecology Notes 6:959-964. https://doi.org/10.1111/j.1471-8286.2006.01470.x

Hanlon RT, Chiao CC, Mäthger LM, Barbosa A, Buresch KC, Chubb C (2009). Cephalopod dynamic camouflage: bridging the continuum between background matching and disruptive coloration. Philosophical Transactions of the Royal Society of London B: Biological Sciences 364:429-437. Https://doi.org/10.1098/rstb.2008.0270

Hebert PD, Stoeckle MY, Zemlak TS, Francis CM (2004). Identification of birds through DNA barcodes. Plos Biology 2(10):e312. https://doi.org/10.1371/journal.pbio.0020312

Hebert PDN, Ratnasingham S, Waard JR (2003). Barcoding animal life: cytochrome C oxidase subunit 1 divergences among closely related species. Proceedings of the Royal Society of London B: Biological Sciences 270:S96-99. https://doi.org/10.1098/rsbl.2003.0025

Herke SW, Foltz DW (2002). Phylogeography of two squid (Loligo pealei and L. plei) in the Gulf of Mexico and Northwestern Atlantic Ocean. Marine Biology 140:103-115. https://doi.org/10.1007/s002270100680

Hubert N, Hanner R, Holm E, Mandrak NE, Taylor E, Burridge M, ... Bernatchez L (2008). Identifying Canadian freshwater fishes through DNA barcodes. PLoS One 3:e2490. https://doi.org/10.1371/journal.pone.0002490

Kimura M (1980). A simple method for estimating evolutionary rates of base substitutions through comparative studies of nucleotide sequences. Journal of Molecular Evolution 16:111-120. https://doi.org/10.1007/BF01731581

Kumar S, Tamura K, Peterson D, Peterson N, Stecher G, Nei M (2011). MEGA5: Molecular evolutionary genetics analysis using maximum likelihood, evolutionary distance, and maximum parsimony methods. Molecular Biology and Evolution 28:2731-2739. https://doi.org/10.1093/molbev/msr121 
Murphy JM, Balguerias E, Key LN, Boyle PR (2002). Microsatellite DNA markers discriminate between two Octopus vulgaris (Cephalopoda: Octopoda) fisheries along the Northwest African Coast. Bulletin of Marine Science 71:545-553.

Pratasik SB, Sambali H, Manoppo L, Tilaar FF, Salaki MS (2019). Genetic variations of cuttlefish Sepia latimanus (Cephalopoda, Sepiidae) in North Sulawesi waters, Indonesia. Aquaculture, Aquarium, Conservation \& Legislation 12(3):792-803.

Ratnasingham S, Hebert PDN (2007). BOLD: the barcode of life data system. Molecular Ecology Notes 7:355-364. https://doi.org/10.1111/j.1471-8286.2007.01678.x

Sambrook SJ, Russel DW, Janssen KA, Irwuin NJ (2001). Molecular cloning: a laboratory manual. $3^{\text {rd }}$ edn. Cold Spring Harbour Laboratory Press, Cold Spring Harbour, New York.

Strugnell JM, Lindgren AR (2007). A barcode of life database for the Cephalopoda? Considerations and concerns. Reviews in Fish Biology and Fisheries 17:337-344. https://doi.org/10.1007/s11160-007-9043-0

Voight JR (1993). A cladistic reassessment of Octopodid classification. Malacologia 35:343-349.

Ward RD, Zemlak TS, Innes BH, Last PA, Hebert PDN (2005). DNA barcoding Australia fish species. Philosophical Transactions Royal Society B: Biological Sciences 360(1462):1847-1857. https://doi.org/10.1098/rstb.2005.1716

Yalla SK, Mohanraju R (2019). DNA barcoding of commercially important cephalopods from Andaman Islands, India. Regional Studies in Marine Science 25:100479. https://doi.org/10.1016/j.rsma.2018.100479

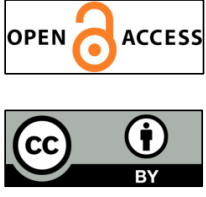

The journal offers free, immediate, and unrestricted access to peer-reviewed research and scholarly work. Users are allowed to read, download, copy, distribute, print, search, or link to the full texts of the articles, or use them for any other lawful purpose, without asking prior permission from the publisher or the author.

License - Articles published in Notulae Scientia Biologicae are Open-Access, distributed under the terms and conditions of the Creative Commons Attribution (CC BY 4.0) License.

(C) Articles by the authors; SHST, Cluj-Napoca, Romania. The journal allows the author(s) to hold the copyright/to retain publishing rights without restriction. 